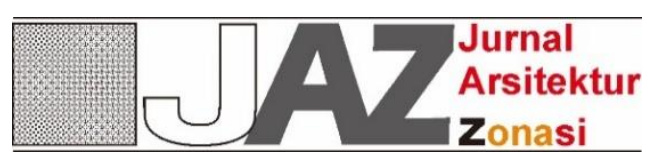

http://ejournal.upi.edu/index.php/jaz - e-mail: jurnal.zonasi@gmail.com dan jurnal zonasi@upi.edu doi.org/10.17509/jaz.v3i2.24683

\title{
KAJIAN ARSITEKTUR MODERN PADA PRASARANA SEKOLAH KEBERBAKATAN OLAHRAGA (SKO)
}

\author{
Article History: \\ First draft received: \\ 16 Mei 2020 \\ Revised: \\ 22 Juni 2020 \\ Accepted: \\ 24 Juni 2020 \\ Final proof received: \\ Print: \\ 30 Juni 2020 \\ Online \\ 4 Juli 2020
}

Jurnal Arsitektur ZONASI

is indexed and listed in

several databases:

SINTA 4 (Arjuna)

GARUDA (Garda Rujukan Digital)

Google Scholar

Dimensions

oneSearch

BASE

Member:

Crossref

RJI

APTARI

FJA (Forum Jurna Arsitektur)

IAI

AJPKM

\author{
Muhammad Rizki Teguh Tri Wicaksono ${ }^{1}$ \\ Lutfi Prayogi ${ }^{1}$ \\ 1,2 Universitas Muhammadiyah Jakarta, Jakarta, Indonesia \\ Jl. Cempaka Putih Tengah 27, RT.11/RW.5, Cemp. Putih Tim., Kec. Cemp. Putih, Kota \\ Jakarta Pusat, Daerah Khusus Ibukota Jakarta 10510 \\ Email: 2016460033@ftumj.ac.id \\ lutfi.prayogi@ftumj.ac.id
}

Abstract: Modern Architecture is one of the famous concepts from the past until now. Modern architectural style that eliminates the style of ornamentation is one of the strong characteristics of modern architecture. By making the building more minimalist modern architecture has a good impact on the world of architecture to the present. One of them is modern architecture in infrastructure or sports hall, to achieve good quality facilities becomes a very important role in the world of sports. The application of modern architecture to sports buildings can be seen in the looks and plans of buildings of its sports facilities. The case study used for this research is the Middle School / High School for Sports, Ragunan. By examining some parts of the principles of modern architecture, namely: The use of basic geometric shapes, the use of elements of field and volume lines, the symmetrical impression on buildings, the use of grid systems, the honesty of construction and structure. The conclusion is that the building of a special sports school in the Ragunan has used Modern Architecture from the principles that have been used as well as the results of the analysis.

Keywords : Architecture; Modern Architecture; Principal Architecture

\begin{abstract}
Abstrak: Arsitektur Modern merupakan salah satu konsep yang terkenal dari dulu hingga sekarang. Gaya arsitektur modern yang menghilangkan corak ornamen merupakan salah satu ciri khas yang kental dari Arsitektur modern. Dengan menjadikan bangunan menjadi lebih minimalis arsitektur modern membawa dampak yang baik pada dunia arsitektur hingga saat ini. Salah satu nya adalah arsitektur modern pada prasarana atau gedung olahraga, untuk mencapai kualitas yang bagus fasilitas menjadi peran yang sangat penting dalam dunia olahraga. Penerapan arsitektur modern pada gedung olahraga bisa terlihat pada tampak dan denah dari bangunan fasilitas olahraga nya. Studi kasus yang dipakai untuk penelitian ini adalah SMP/SMA Sekolah Khusus Olahraga, Ragunan. Dengan meneliti beberapa bagian dari prinsip arsitektur modern yaitu: Penggunaan bentuk dasar geometri, Penggunaan unsur garis bidang dan volume, Kesan Simetris pada bangunan, Penggunaan sistem grid, Kejujuran konstruksi dan struktur. Kesimpulanya bahwa pada bangunan Sekolah khusus olahraga di Ragunan telah menggunakan Arsitektur Modern dari prinsip-prinsip yang telah gunakan serta hasil analisis.
\end{abstract}

Kata Kunci: Arsitektur; Arsitektur Modern; Prinsip Arsitektur

\section{Pendahuluan}

Indonesia merupakan salah satu negara dengan kekayaan yang berlimpah, mulai dari kekayaan sumber daya alam hingga sumber daya manusia. Oleh karena itu, Indonesia di sebut sebagai negara dengan hamparan seribu pulau. Disamping itu Indonesia juga terdiri dari beraneka ragam suku, ras, budaya, agama dan sebagainya. Indonesia sendiri kaya akan potensi-potensi dari sumber daya manusia nya, Salah satu potensi-potensi yang di miliki oleh sumber daya manusia Indonesia yaitu adalah pada bidang olahraga mulai dari anak-anak hingga orang dewasa. Olahraga sendiri terbagi menjadi beberapa jenis karena pada 
zaman Nabi pun olahraga sudah di lakukan, sedangkan di Indonesia olahraga di lakukan pada zaman kerajaan yang dimana salah satu fungsinya adalah untuk perlindungan diri terhadap serangan hewan yang ganas, dan berbagai olahraga yang dilakukan pada zaman dahulu adalah seperti olahraga renang, kuda, panahan, lari, bela diri, dan gulat (adara primadia,2017) indonesia merupakan negara di Asia Tenggara yang di bidang olahraga nya berkembang pesat dan menjadikan kegiatan olahraga ini tidak dapat dipisahkan dari kehidupan sehari-hari yang dilakukan oleh masyarakat Indonesia dari dulu hingga sekarang.

Karena perkembangan zaman yang mulai canggih dan sudah memasuki era modernitas pemerintah terus bergerak dalam memajukan bidang olahraga di Indonesia, salah satu upaya pemerintah adalah dengan mendirikan Sekolah Khusus Olahraga (SKO) salah satunya di daerah Ragunan, Jakarta. Dan diberbagai daerah yang ada di Indonesia Lain nya, karena SKO sendiri merupakan wadah bagi kaum muda yang mau menyalurkan hobi dan ingin bergerak maju demi mengharumkan nama Indonesia di kancah Internasional. Sekolah Keberbakatan olahraga, Ragunan pada dasar nya sama dengan sekolah-sekolah umum lainya, selain di khususkan untuk olahraga tidak lupa juga untuk prestasi Akademik nya. Tujuan dari sekolah ini adalah untuk melahirkan atlit hebat dan berbakat untuk kejuaraan nasional maupun kejuaraan internasional demi lambang Garuda di dada. Karena Sekolah Khusus Olahraga, Ragunan memiliki aktivitas yang tinggi olahragawan / atlit membutuhkan sebuah fasilitas latihan yang dapat mempermudah pengguna nya menikmati tempat tersebut, serta memberi kesadaran akan pentingnya hidup sehat kepada masyarakat. Arsitektur Modern menjadi salah satu idenyang cemerlang yang dapat mendukung Sekolah Khusus Olahraga (SKO) karena begitu pesatnya kecanggihan teknologi untuk sesuatu yang ekonomis, mudah, dan bagus merupakan faktor yang di perhitungkan untuk prasarana Sekolah Khusus Olahraga (SKO) (Dede Meirianta,2015). Adapun rumusan penelitian adalah:

1. Bagaimana aplikasi konsep Arsitekur Modern pada bangunan Sekolah Keberbakatan Olahraga (SKO)?

2. Bagaimanakah bentuk fasad yang sesuai dengan konsep Arsitektur Modern pada bangunan olahraga?

\section{Arsitektur Modern}

Arsitektur Modern adalah istilah sejumlah bangunan dengan berbagai bentuk sederhana dengan menghilangkan ornamen segala macam nya. Karakteristik muncul sekitar tahun 1900 lalu pada tahun 1940 dikenal dengan gaya dan aliran internasional menjadi yang dominan untuk beberapa abad ke-2 ini. Harry Francis Mallgrave "Modern Architectural Theory" dalam buku nya menjelaskan Arsitektur modern "too rigid" kelakuan desain melalui perubahan dari konsep arsitektur sebelumnya. Pada sejarahnya arsitektur modern pada zaman Yunani dan Gotik kemudian diadaptasikan kepada konsep penimbunan desain lama yang penuh dengan ornamen dan bentuk yang dramatis menjadi lebih monoton dan kaku. Tujuan dari Arsitektur Modern adalah penggunaan gaya murni dengan tidak adanya ornamen karena dianggap sebagai pemborosan yang mencolok pada bangunan. Menurut Larson (1993), mengapa penolakan akan ornamen sangat keras ?, karena hal tersebut didasari oleh prinsip industri yang meminimalisir terhadap efesiensi ekonomi dan bertujuan pada pemurnian bentuk yang selaras dan tidak adanya ornamen - ornamen.

Terdapat aliran-aliran arsitektur modern pada masa 1900-1940 yaitu :

1. Art Nouveau.

Art Nouveau menurut Ashadi (2018) definisi Art Nouveau adalah sejenis Art atau Seni. Art nouveau juga di cirikan dengan bentuk-bentuk yang plastis dan organis tapi juga mengandalkan prinsip geometris, karena perkembangan ternogi dan pengaruh kebudayaan didukungnya oleh industrialisasi dan urbanisasi. Sumalyo yulianto "Arsitektur Modern: Akhir abad XIX dan abad XX Edisi Ke2" dalam buku nya menjelaskan ciri-ciri dari art nouveau adalah :

a. Art Nouveau dalam desain interior membangkitkan kembali gaya Victorian yang dimodernisasikan.

b. Dinamis mengalir dan garis - garis melengkung yang bervariasi.

c. Art Nouveau dari beberapa garis yang berpola lengkungan menjadi suatu kebiasaan untuk karya - karya seniman diseluruh dunia.

2. Arsitektur Organik.

Pengertian Arsitektur Organik menurut Fleming, Honour \& Pevsner merupakan sebuah istilah yang terjadi pada bangunan yang bersifat biologi, alami, atau dapat tumbuh dengan sendirinya. contoh bangunan yang menggunakan bentuk atau ciri dari boimorfik. Pengertian yang lain, Arsitektur Organik menurut Frank Lloyd Wright, Hugo Haring, dan arsitek lainnya adalah arsitektur yang secara terlihat 
ada dengan lingkungan saling berkesinambungan, terorganisir dengan tapak, dan mereflesikan kepedulian arsitek terhadap proses dan bentuk alam yang di hasilkan nya. (Rasikha, 2009).

Terdapat beberapa konsep atau ciri dasar Arsitektur Organik menurut Pearson (2002) sebagai berikut:
a. Building As Nature
b. Coutinous Present
c. Form Follows Flow
d. Of The Hill
e. Of The Material
f. Of The People
g. Young And Unexpected

3. Arsitektur Kubisme

Aliran kubisme mulai berkembang pada tahun 1910-1914 di Paris. Aliran ini muncul karena adanya rasa bosan pada aliran-aliran klasik penuh ornamen. Berasal dari seni lukis yang tidak hanya membuat bentuk, warna satu dimensi tetapi juga berfokus pada waktu, Kubisme tidak sepenuh nya abstrak. Prinsip dari aliran ini adalah menonjolkan 3 aspek : Ruang, Dimensi, Waktu, dalam hal ini tidak adanya aliran kelasik maupun tradisional. Semenjak aliran kubisme muncul arsitektur bukan lagi selubung melaikan penataan ruang yang dominan. "Longman Leamers Dictionary of American English," (2000). Menurut Le corbusier aliran kubisme memiliki prinsip prinsip dasar, yaitu menonjolkan aspek ruang atau tiga dimensi dan waktu. Adapun penerapan yang dipakai dalam karya arsitektur yaitu :

a. Ruang dalam dan ruang - ruang terlihat menyatu.

b. Ruang - ruang yang dapat menyatu dan berhubungan antara satu dengan yang lain.

c. Keterbukaan ruangan dimaksudkan untuk memasukkan cahaya kedalam ruangan.

d. Kesatuan antara ruang menimbulkan kesamaan waktu yang dapat menimbulkan kesinambungan.

e. Terlihat memiliki kesamaan disemua sisi.

4. Arsitektur De Stijl

Arsitektur De Stijl sebuah tren modern pada tahun 1920 sampai tahun 1930 sebelum perang dunia ke II dimulai, yang merupakan gaya arsitektur modern berkembang diambil oleh nama dari sebuah majalah di belanda yang terkenal pada masa itu. Neo Plasticisme adalah pelopor dari De Stijl yang mempunyai makna seni rupa gaya baru. Neo Plasticisme dikembangkan oleh seniman Piet Mondrian yang memaikan warna dasar menjadi ciri utama nya merah, kuning, dan biru sehingga dalam satu karya memiliki ciri chas mondrian dalam penggunaan warna. De Stijl merupakan aliran arsitektur yang lebih abstrak dengan mengutamakan bentuk yang sederhana. De Stijl tumbuh di saat terjaninya perang dunia. Tujuan utama dari aliran ini adalah wujud seni yang disatukan dalam ruang. De Stijl menerapkan proyek rumah liburan De V onl' di Norrdwijerkhout oleh Theo Van Doesberg mengemukakan beberapa ciri dari dari arsitektur De Stijl (1924) :
a. Penggunaan warna yang terang.
b. Penggunaan garis yang kontras.
c. Harmoni dalam komposisisnya.

5. Arsitektur Bauhaus

Ashadi "Peradaban dan Arsitektur Modern" dalam bukunya menceritakan pada tahun 1919, di Weimar, Walter Gropius (1883-1969) ia mendirikan Bauhaus yang artinya "House Of Constrution" sebuah lembaga pendidikan dapat menyatukan para seniman seperti lukis, patung, pengrajin, dan arsitek. Bauhaus hanya bertahan 14 tahun tetapi pengaruh besar telah ditimbulkan pada sekolah lembaga ini kepada dunia dalam waktu yang cukup lama. Gropius berharap banyak kepada arsitekarsitek untuk lebih kratif dengan karyanya dan asli, secara garis besar Arsitektur Bauhaus lebih memperkenalkan dan mendalami konsep arsitektur pada denah dengan segala aktivitas dan organisasi yang ada didalam ruangan tersebut.

6. Gaya Internasional

Aliran yang mulai trend pada tahun 1920-1930 adalah "International Style" yang pada umum nya para arsitek mengacu pada dekade perkembangan gaya modern sebelum perang dunia II. Pada tahun 1950an, Gaya Internasional sebenarnya masih populer pada saat itu diseluruh dunia. Karena Gaya Internasional sama sekali tidak menggunakan variasi yang erat kaitanya dalam desain yang tidak memiliki ornamen serta bentuknya yang sederhana. Tetapi pada waktu itu penerapan Gaya 
internasional yang diwujudkan dalam bangunan industi mengalami permasalahan karena penerapanya yang gagal. Berasal dari sebuah buku oleh Henry - Russell Hitchock dan Philip Johnson, The International Style, yang memiliki karakteristik umum untuk modernisasi didunia. Terence Relay dan Stephen Perella dalam buku nya "The international style: exhibition 15 and the Museum of Modern Art” (1992) menjelaskan beberapa ciri umum dari Gaya Internasional :
a. Penyederhanaan bentuk.
b. Penghilangan ornamen pada jendela, kaca, serta fasad.
c. Konstruksi yang jujur.
d. Menggunakan material fabrikasi.
e. Bentuk geometri kubus sederhana.
f. Fasad memiliki 90 derajat.
g. Jendela dengan garis horizontal yang beraturan.
h. Bentuk mengikuti fungsi.

\section{Prinsip Arsitektur Modern}

Dari beberapa aliran Arsitektur Modern dari abad ke 1900-1940an terdapat beberapa prinsip pada Arsitektur Modern yang digunakan dalam penelitian ini menggunakan prinsip dari Arsitektur Gaya Internasional. Serta dapat di simpulkan beberapa prinsip-prinsip Arsitektur Modern:
a. Penggunaan bentuk dasar geometri.
b. Penggunaan unsur, garis, bidang, dan volume.
c. Kesan simetris pada bangunan.
d. Penggunaan sistem grid.
e. Kejujuran struktur dan konstruksi.

\section{Pengertian Sekolah dan Tanggung Jawab Sekolah}

Sekolah adalah sistem interaksi sosial keseluruhan diri atas interaksi diri sendiri, bersama dalam suatu hubungan organisasi (Wayne dalam buku Soebagio Atmodiwiro, 2000:37). Adapun berdasarkan undangundang no 2 tahun 1989 Sekolah adalah satuan yang berjenjang dan berkesinambungan untuk masa depan. Sekolah juga merupakan tempat belajar seperti membaca, menulis dan belajar untuk berprilaku baik. Juga menjadi lingkungan kedua tempat anak-anak berlatih dan menumbuhkan kepribadiannya. (Zanti Arbi dalam buku Made Piderta, 1997:171).

Sedangkan untuk tanggung jawab sekolah yaitu Sekolah memiliki tanggung jawab yang besar terhadap perkembangan peserta didik dengan menyuguh kan komponen-komponen sekolah secara maksimal dalam kehidupan bermasyarakat yang bersifat nyata disekitarnya (Daryanto : 1997:544).

\section{Pengertian Sekolah Keberbakatan Olahraga (SKO)}

Sekolah keberbakatan olahraga merupakan salah satu upaya dari pemerintah untuk memberikan pelayanan pendidikan yang tidak hanya berfokus pada umum nya tetapi juga di khusus kan untuk peserta didik yang memiliki potensi bakat istimewa yang ingin dikembangan atau bagi pesarta didik yang ini bercita-cita menjadi atlit nasional. Sekolah keberbakatan olahraga sendiri didirikan oleh menteri olahraga yang berkerja sama dengan menteri pendidikan nasional yang berdasarkan (UU no 003 tahiun 2005) tentang sistem keolahragaan nasional. Pelatihan pada Sekolah Keberbakatan Olahraga (SKO)

\section{Kelas Berbasis Olahraga}

Upaya yang diterapkan pada Sekolah Keberbakatan Olahraga (SKO) adalah pembentukan kelas berbasis olahraga yaitu salah satu ruang belajar yang hanya berfokuskan pada pembelajaran olahraga. Seperti menampilkan audio visual, pemutaran film olaharaga, dll. Pembentukan kelas berbasis olahraga memiliki beberapa komponen - komponen yang dimaksudkan yaitu :

a. Sebagai pembinaan olahraga yang memiliki pelayanan pendidikan mengacu pada prestasi.

b. Pembinaan dengan pelayanan pendidikan sebagai wadah masyarakat dan pemerintah bersama sama mewujudkan Sekolah Keberbakatan Olahraga (SKO) dimana para peserta didik yang memiliki bakat digabungkan dalam satu atau beberapa kelas yang disebut dengan kelas berbasis olahraga.

\section{Objek Penelitian}

Terdapat objek penelitian yang dapat diperoleh dan membantu penulis untuk melakukan penelitian dari kajian arsitektur modern yaitu pada bagian : 


\section{a. Denah}

Pada penelitian objek denah dibutuhkan karena dalam Arsitektur Modern denah sangat berpengaruh dalam penelitian dengan mengetahui bentuk ruang yang efisien dan fungsional, ukuran standar ruang, dan apa saja nama ruang yang ada didalam nya dalam objek penelitian prasarana olahraga yang akan dibutuhkan.

b.Fasad

Gaya arsitektur modern merupakan gaya arsitektur statis yang berkembang pada masa pra-industrial sebagai bentuk dari revolusi dari gaya arsitektur tradisional.

c. Material

Dalam Arsitektur Modern beberapa bahan material yang digunakan seperi kayu, kaca, beton, dan besi kerap digunakan karena keberadaan material sangat mudah terlihat dan terasa pada bangunan baik dari segi eksterior maupun interior atau dengan menutupi tampak bangunan dengan material yang artistik.

d. Konstruksi

Modernitas pada bangunan umumnya tidak terlihat dan hanya terletak pada fungsi perencanaan nya, bentuk-bentuk yang tersebar secara merata pada permukaan menyembunyikan material yang telah dibangun. Oleh karena itu, konstruksi sangat berpengaruh pada penelitian tentang Arsitektur Modern terhadap bangunan.

\section{Metode Penelitian}

Sebuah metode yang bersifat deskriptif, analisis mengacu pada data memanfaatkan teori yang ada sebagai pendukung, serta dapat menghasilkan teori. Penelitian kualitatif merupakan jenis penelitian ilmu sosial yang mengumpulkan dan berkerja dengan data observasi serta eksperimen berdasarkan kajian literatur serta dari sudut pandang deskriptif sesuai gambaran permasalahan dan fakta yang ada di lapangan. Menurut Sugiyono (2009:15), metode kualitatif yang digunakan untuk menyelidiki, menemukan, menggambarkan, dan menjelaskan kualitas atau keistimewaan dari pengaruh sosial. Tujuan dari penelitian kualitatif adalah menjelaskan fenomena secara dalam lagi yang dilakukan saat mengumpulkan data secara lengkap yang menjadi sesuatu yang sangat penting. Tahapan selanjut nya dalam penelitian adalah dengan melakukan pengumpulan data yaitu Observasi dan dokumentasi, setelah itu pengumpulan data dari yang sudah di kaji maupun didapat, melakukan penyajian data, dan kesimpulan.

\section{Hasil dan Pembahasan}

\section{Sekolah SMP/SMA Ragunan, DKI Jakarta}

Lokasi penelitian Sekolah SMP/SMA Ragunan, Jakarta Selatan. Alamat: Jl. Komplek Gor Ragunan, Ragunan, Pasar Minggu, RT.9/RW.7, Ragunan, Jakarta Selatan, Kota Jakarta Selatan, Daerah Khusus Ibukota Jakarta 12550.

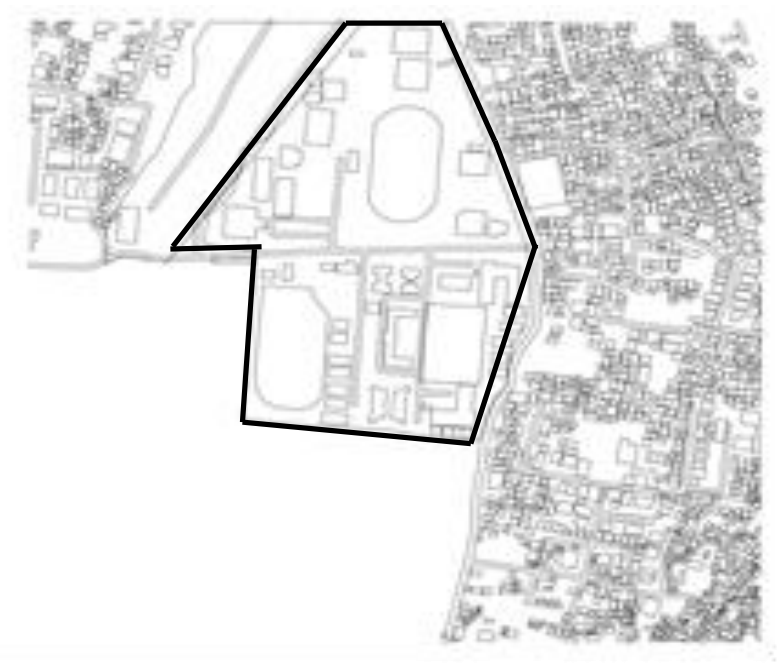

Gambar 1. Lokasi Sekolah SMP/SMA Ragunan Sumber : Data Peneliti, 2019 
Penelitian pada studi kasus Sekolah SMP/SMA Ragunan terbagi menjadi beberapa objek yang akan diteliti yaitu pada bagian denah, fasad, material dan konstruksi dan mengacu pada prinsip - prinsip Arsitektur Modern sebagai berikut:

1. Analisis Bentuk Geometri

Bentuk dasar geometri dalam Arsitektur Modern merupakan salah satu prinsip penting yang harus ada, karena bentuk dasar Geometri dapat mempengaruhi sebuah rancangan desain. Bentuk-bentuk dasar geometri untuk bidang Arsitektur adalah sebagai input mengenai kekayaan bentuk-bentuk geometri sebagai dasar untuk mendapatkan nilai estetika dalam bangunan.

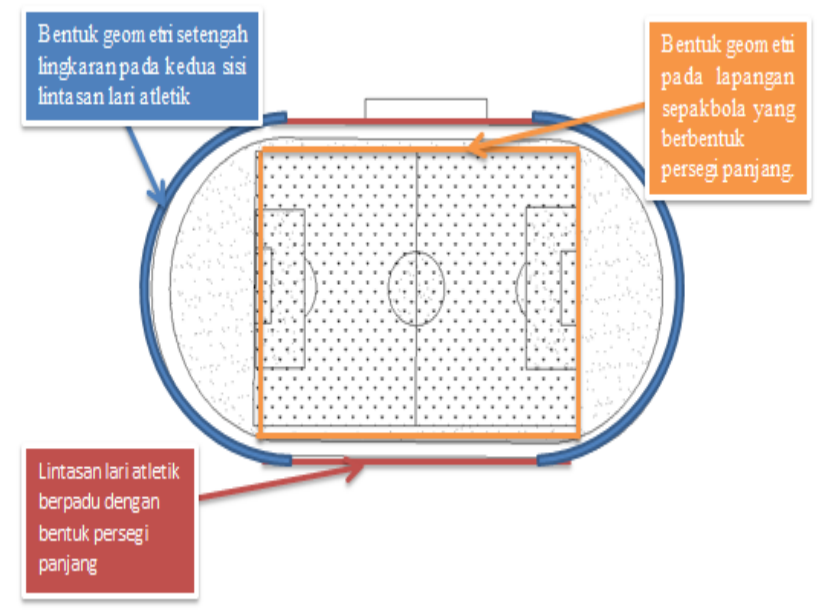

Gambar 2. Denah Lapangan Sepakbola Ragunan Sumber : Data Peneliti, 2019

Bagian tampak yang elegan dengan bentuk geometri persegi dan persegi panjang. Contoh sedikit dikombinasikan atau divariasikan pada salah satu bentuk massa yang dimiringkan sangat menarik untuk dilihat.

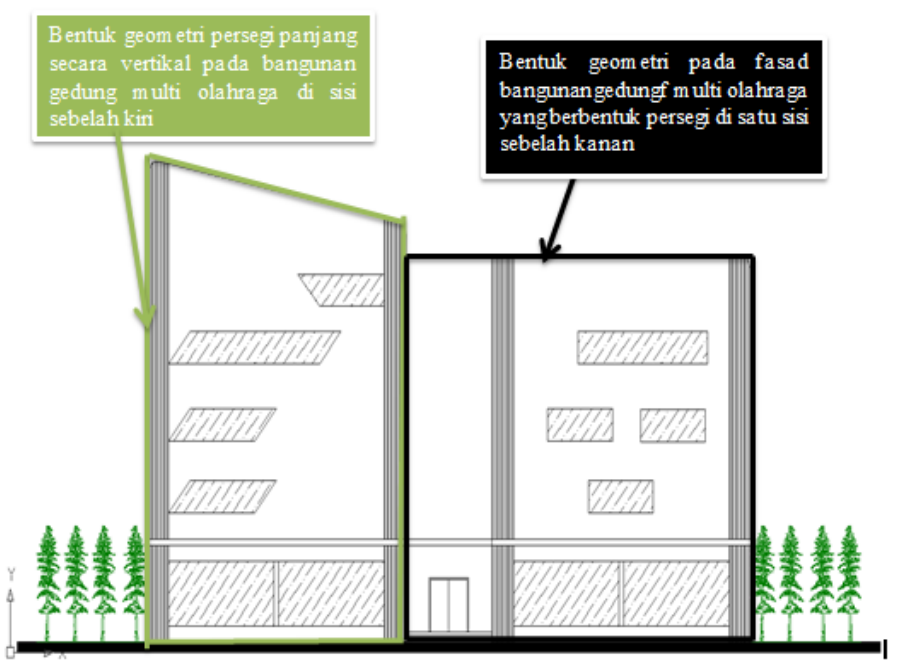

Gambar 3. Fasad Geometri Gedung Multi Olahraga Sumber : Data Peneliti, 2019

2. Analisis Penggunaan Garis, Bidang, Volume

Seperti hal nya unsur garis secara konseptual adalah sebuah garis memiliki panjang tetapi tidak memili lebar atau tinggi, sedangkan dalam unsur bidang pada dasarnya sebuah bidang memiliki panjang dan lebar, tetapi tidak memiliki tinggi. Wujud adalah karakter utama yang dimiliki oleh sebuah bidang. Wujud ditentukan oleh kontur garis yang membentuk sisi-sisi sebuah bidang. Ciri-ciri pendukung lain yang dimiliki sebuah bidang yaitu warna permukaannya, pola dan tekstur mernpengaruhi bobot dan stabilitas secara visualnya dalam kornposisi suatu konstruksi visual, suatu bidang berfungsi untuk membentuk batas-batas sebuah volume, Sedangkan volume adalah sebuah bidang yang diperluas dalam arah yang berbeda dari arah asalnya akan menjadi sebuah ruang. Secara konsep, Sebuah volume mempunyai tiga dimensi, yaitu: panjang, Iebar, dan tinggi. 
Salah satu bangunan yang berada di SMP/SMA Sekolah Khusus Olahraga Ragunan, yaitu bangunan gedung Kolam Renang yang memainakan unsur garis untuk menonjolkan bagian fasad yang bisa menjadi sebuah bidang, dengan bentuk fasad yang unik juga gedung kolam renang ini terlihat seperti berundakundak dengan menaikan bagaian bidang tinggi dan rendah nya.

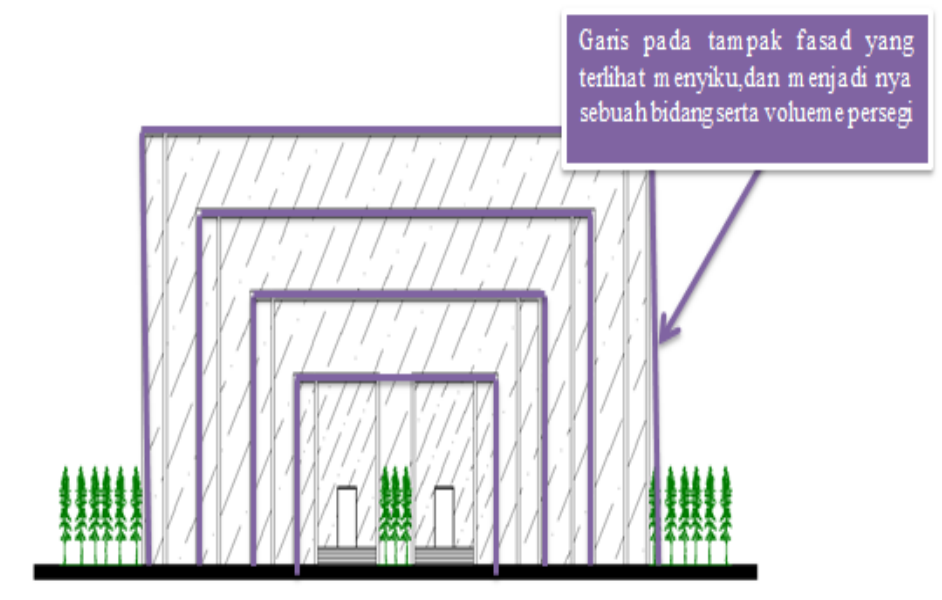

Gambar 4. Fasad Gedung Kolam Renang Garis, Bidang, Volume Sumber : Data Peneliti, 2019

3. Kesan Simetris Pada Bangunan

Kesan simetris yang terjadi pada bangunan yang berada di SMP/SMA Sekolah Khusus Olahraga, Ragunan terlihat simetris seperti pada bangunan voli indoor, yang tampak fasad nya sejajar atau sesuai dengan proporsi bangunan dengan eksterior nya. Kesan simetris yang terjadi adalah dengan setara nya ukuran dengan bentuk fasad yang menyesuaikan dengan denah.

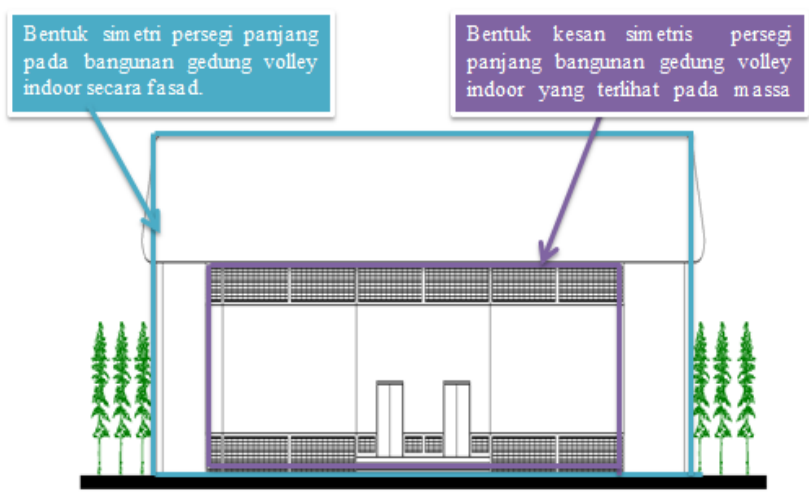

Gambar 5. Fasad Gedung Voli Indoor Kesan Simetris Sumber : Data Peneliti, 2019

4. Penggunaan Sistem Grid

Pada bangunan oalah raga yang ada di dalam SMP/SMA Sekolah Khusus Olahraga ragunan dapat dilihat dari penggunaan sistem grid dengan jarak 6x6 meter antar kolom. Tetapi penggunaan jarak antar kolom di tengah karena terdapat lapangan dari voli indoor tersebut dengan jarak panjang antar kolom 24 meter horizontal.

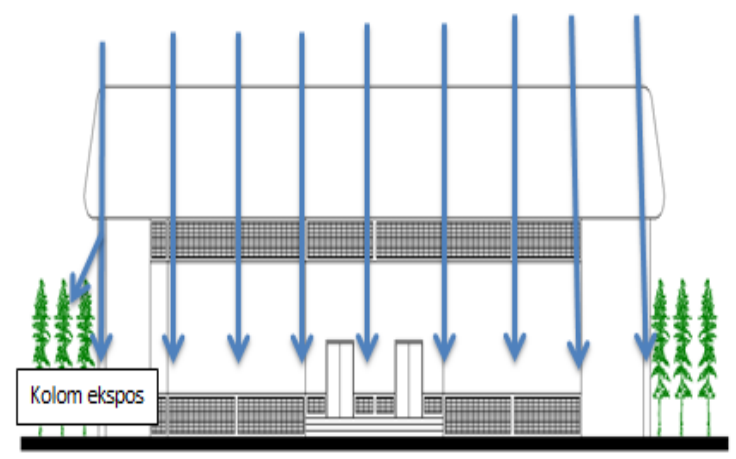

Gambar 6. Fasad Gedung Voli Indoor Grid Sumber : Data Peneliti, 2019 
Penggunaan bentuk sistem grid yang terjadi dapat berpengaruh terhadap tampak bangunan, bagaimana tampak pada bangunan voli indoor memainkan gubahan massa dengan menonjolkan beberapa kolom yang terekspos.

5. Kejujuran Stuktur dan Konstruksi

Prinsip terakhir yang terdapat dalam Arsitektur Modern adalah kejujuran struktur dan konstruksi, pada studi kasus kejujuran konstruksi yang terlihat adalah pada fasad bangunan SMP/SMA Sekolah Khusus Olahraga Ragunan, yaitu pada bangunan multi olahraga dan gedung kolam renang, menggunakan kejujuran struktur dan konstruksi dari penggunaan beton pada hampir keseluruhan dinding.

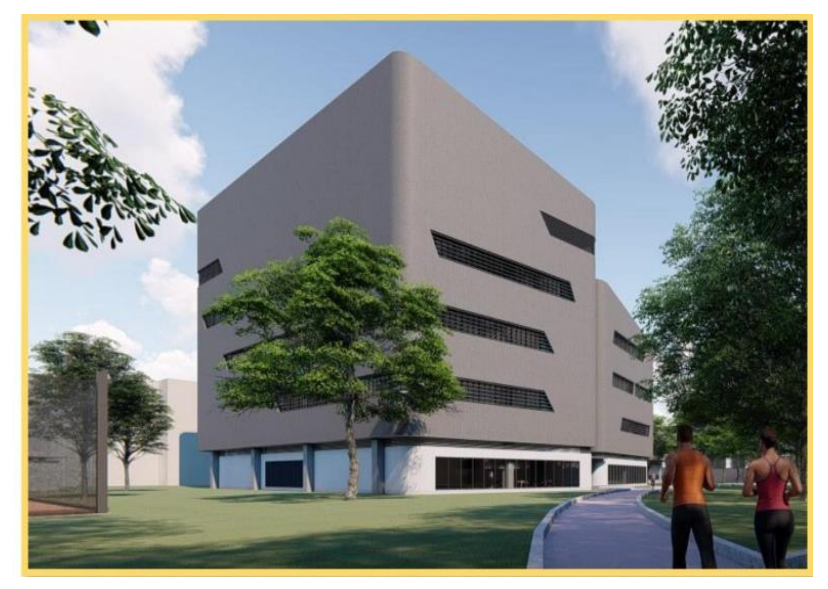

Gambar 7. Fasad Konstruksi Gedung Multi Olahraga Sumber : Data Peneliti, 2019

Lalu selain gedung multi olahraga, terlihat juga pada bagian dinding kiri dan kanan serta atas yang menggunakan beton ekspos secra berundak undak dan pengunaan murni kaca lebar pada fasad bangunan dari gedung kolam renang pada gambar 8 dibawah ini.

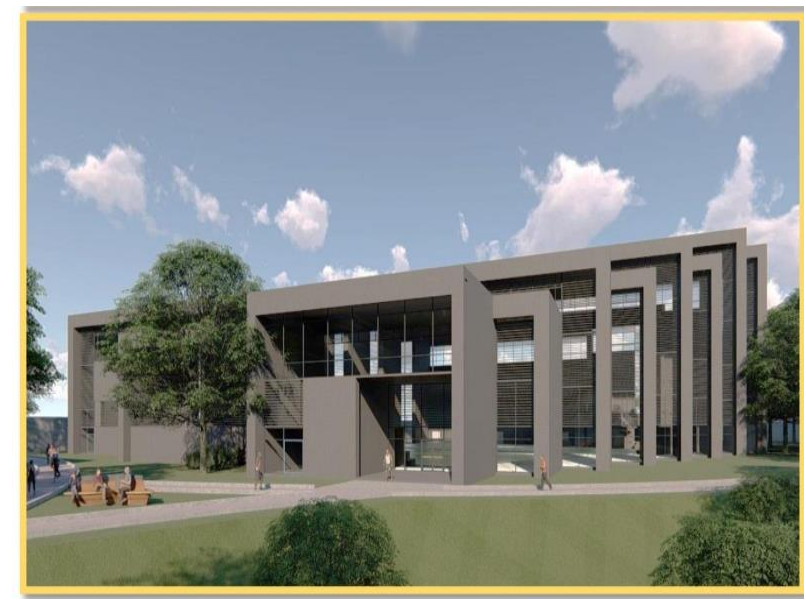

Gambar 8. Fasad Konstruksi Gedung Kolam Renang Sumber : Data Peneliti, 2019

\section{Kesimpulan}

Berdasarkan penelitian mulai dari bagaimana cara memecahkan rumusan masalah yaitu penerapan serta bentuk pada fasad dari bangunan fasilitas prasarana sekolah khusus olahraga dengan prinsip - prinsip Arsitektur Modern, pada penelitian studi kasus yang telah ditentukan yaitu 1.SMP/SMA Sekolah Khusus Olahraga (SKO) Ragunan, Memulai dengan mengkaji apa itu arsitektur modern, adapun arsitektur modern terdpaat aliran - aliran pada tahun 1900 - 1940an dengan berisikan 6 aliran kemudian di simpulkan kembali menjadi 5 prinsip yang akan di gunakan lalu menerapkan nya pada bangunan studi kasus yang telah ditentukan.

Prinsip - prinsip arsitektur modern tersebut adalah :

1. Penggunaan bentuk geometri

2. Penggunaan unsur garis, bidang dan volume

3. Kesan simetris pada bangunan

4,penggunaan sistem grid 
5. Kejujuran struktur dan konstruksi

Pada studi kasus yang telah di teliti dan di analisis, bahwa pada bangunan prasarana Sekolah khusus olahraga, Ragunan memperlihatkan secara keseluruhan dari 5 poin tersebut telah menggunakan konsep atau prinsip-prinsip arsitektur modern.

\section{Ucapan Terimakasih}

Terimakasih yang sebesar - besarnya serta mengucap rasa syukur atas selesainya tulisan ini, tak lupa terimakasih saya ucapkan untuk pihak yang terlibat atas dukungan yang dalam menyusun tulisan penelitian ini. Terimakasih kepada Jurnal Arsitektur Zonasi (JAZ) yang telah menyediakan fasilitas untuk mereview dan mem publish sehingga dapat bermanfaat bagi yang membutuhkan.

\section{Referensi}

Ashadi. 2016. Peradaban dan Arsitektur Modern. Penerbit Arsitektur UMJ Press. Jakarta.

Setiawan, D. Utami, T. B. (2016). Tipologi Perubahan Elemen Fasad Bangunan Ruko pada Penggal Jalan Puri Indah, Jakarta Barat. Vitruvian Jurnal Arsitektur, Bangunan dan Lingkungan, Vol. 6 No. 1, 1524

Mallgrave, H.F. 2005. Modern Architectural Theori. Published in the United States of America by Cambridge University Press, New York.

Sinaga, R. Dan Tinangon, Alvin. 2011. Arsitektur New Brutalisme. Media Matrasain Vol. 8 No. 2. Sulawesi Utara. Universitas Sam Ratulangi.

Hanifan, Rifky. 2018. Penerapan Unsur-Unsur Art Deco Pada Stasiun Kereta Api Bandung. Respository Jurnal Tugas Akhir Arsitektur Itenas No. 1 Vol. III. Bandung. Itenas.

Gunawan K. D. E. dan Prijadi R. 2011. REAKTUALISASI RAGAM ART DECO DALAM ARSITEKTUR KONTEMPORER.Media matrasain Vol. 8 No. 1. Sulawesi Utara. Universitas Sam Ratulangi.

Sujanra, Ummul, dan Wahyuwibowo. 2017. PENERAPAN TEORI ARSITEKTUR ORGANIK DALAM STRATEGI PERANCANGAN PUSAT PENGEMBANGAN INDUSTRI KREATIF DI BANDUNG. Arsitektura, Vol. 15 No. 2. Surakarta. Universitas Sebelas Maret.

Patria, Surya. 2013. Bauhaus Awal Sekolah Desain. Dimensi, Vol. 10. No. 1. Jakarta. Universitas Trisakti.

Umar, D. 2014. Perkembangan Arsitektur:Arsitektur Klasik dan Arsitektur Modern. Academia. Makassar. Universitas Muslim Indonesia.

La Sunu, Asbas A., dan Labulan. 2016. Manajemen Sekolah Khusus Olahragawan Internasional. Volume 1, Nomor 1. Samarinda. Universitas Mulawarman.

Mahendra, Agus. 2017. Pengembangan Manajemen Kelas Olahraga. Junral terapan Ilmu Keolahragaan Vol. 02 No. 02. Bandung. Universitas Pendidikan Indonesia.

Sujanra, Mustaqimmah, dan Wahyuwibowo. 2017. Penerapan Arsitektur Organik dalam Strategi Perancangan Pusat Pengembangan Industri kreatif di Bandung. Arsitektura, Vol. 15, No. 2. Surakarta. Universitas Sebelas Maret. 